Food and Nutrition (Un)Governance

(Des)Governação da Alimentação e Nutrição

\title{
Francisco Sarmento
}

aGter - Ameliorer la Gouvernce de la Terre, e l'Eau et des Ressources naturelles 45 bis aveue de la Belle Gabrielle, 94736 Nogent sur Marne, France

Email: fbendrau@hotmail.com

\begin{abstract}
This article discusses, from a political economy perspective, the complexity of food and nutrition security governance, including different views underlying the expected role that such governance should play in agriculture food security and nutrition.
\end{abstract}

Keywords: governance; food; policy

\section{Resumo}

$\mathrm{O}$ artigo discute numa perspectiva de economia politica, a complexidade da governança da segurança alimentar e nutricional e diferentes visões subjacentes ao papel dessa mesma governança na agricultura, segurança alimentar e nutrição.

Palavras-Chave: governação; alimentação; políticas 


\section{Introduction}

Examining the ongoing global debate ${ }^{1}$ about agriculture and nutrition, one inconvenient truth comes to the fore: it is on the growing discrepancy between food as a biological and cultural phenomenon or a simply set of products or (and) services that relies one of the biggest present challenges for humanity. While in the North, food is becoming a fetishist commodity for television entertainment ${ }^{2}$, ready-to-use therapeutic foods are being increasingly offered to donor agencies and governments to treat acute malnutrition in the South. Both processes are sides of the same coin - the recent evolution of our food system and the prevailing policy and program options being taken at global level. This article will briefly analyse how global multilateral food and nutrition governance mechanisms are being increasingly influenced by specific groups of interest and its possible implications for our future.

\section{Recent evolution of our food system}

The need for global governance of food led to the creation of the United Nations Food and Agriculture Organization (FAO) in 1945. The FAO council, its governing body, respects the rule "one country, one vote".

Despite the social, economic and environmental externalities generated, food production has increased in the last 70 years, enabling a $40 \%$ rise in food intake per person for a population that has swollen from 2.5 billion to around 7 billion. This is enough to provide everyone with at least 2,720 kilocalories (kcal) per person per day, which in turn has contributed to a better understanding of the most important policy challenge in our food system: to ensure universal access to healthy and adequate food from more sustainable and equitable production practices ${ }^{3}$. However, since the mid-1990s, FAO has lost half its staff and more than $40 \%$ of its budget. Generally speaking, we can observe that during the last decades, as OECD governments added on new multilateral institutions such as the World Food Programme (WFP), the Consultative Group on International Agricultural Research (CGIAR) and the International Fund

\footnotetext{
${ }^{1}$ The global debate has been driven by concerns related with the sustainability of the food system having in mind the expected population growth through 2030 as well its social, economic, health and environmental impacts.

2 The paradox is that the average time available for preparing a family meal lies today in 15 minutes; Only half of all family meals contains a "fresh" food item.

3 For example, The Global Framework for Food Security and Nutrition (CFS) or FAOs Strategic Objective number 1 - Help Eliminate Hunger, Food Insecurity and Malnutrition
}

\section{Introdução}

Examinando o debate global em curso ${ }^{1}$ sobre agricultura e nutrição uma inconveniente verdade vem à tona: é na crescente discrepância entre a comida como um fenómeno biológico e cultural ou simplesmente um conjunto de produtos ou serviços que surge um dos maiores desafios para a humanidade. Enquanto no Norte, a comida está se tornando uma commodity em programas fetichista de entretenimento televisivo ${ }^{2}$, alimentos terapêuticos prontos a usar são cada vez mais oferecidos às agências doadoras e aos governos para tratamento da desnutrição aguda no Sul. Ambos os processos são faces da mesma moeda - a evolução recente do nosso sistema alimentar e as políticas e opções tomadas a nível global. Este artigo irá analisar brevemente como o sistema alimentar multilateral global e seus mecanismos de governança estão sendo cada vez mais influenciados por grupos de interesse específicos e suas possíveis implicações para o nosso futuro.

\section{Evolução recente do nosso sistema alimentar}

A necessidade de melhor governança global da alimentação levou à criação da Organização das Nações Unidas para a Agricultura e Alimentação (FAO) em 1945 com um Conselho respeitando a regra - um país, um voto.

Apesar das diversas externalidades económicas e ambientais a produção de alimentos aumentou nos últimos 70 anos, permitindo um aumento de $40 \%$ na disponibilidade per-capita de alimentos para uma população que saltou de 2,5 mil milhões para cerca 7 mil milhões. Isso é suficiente para proporcionar a todos os habitantes do planeta pelo menos 2.720 quilocalorias (kcal) por pessoa/dia. Isto tem contribuído para uma maior compreensão de um dos desafios mais importante no nosso sistema alimentar: como garantir o acesso universal a uma alimentação adequada e saudável, proveniente de práticas de produção mais sustentáveis e equitativas ${ }^{3}$. No entanto, desde meados da década de 1990, a FAO perdeu metade dos seus funcionários e mais de $40 \%$ do seu orçamento.

De um modo geral, podemos observar que durante as

${ }^{1} \mathrm{O}$ debate global tem sido impulsionado por preocupações relacionadas com a sustentabilidade do sistema alimentar, tendo em vista o crescimento esperado da população até 2030, bem como suas externalidades sociais, econômicas, de saúde e ambientais.

${ }^{2} \mathrm{O}$ paradoxo é que o tempo médio disponível para preparar uma refeição em família é hoje de 15 minutos; Só metade de todas as refeições em família contém um item alimentar "frescos".

3 Por exemplo, o quadro Global para a Segurança Alimentar e Nutricional (GFS) ou objectivo estratégico 1 da FAO - ajudar a eliminar a fome a insegurança alimentar e a desnutrição 
for Agricultural Development (IFAD), support for FAO has declined accordingly [1].

Concurrently, new technologies developed over the last three decades have enabled the industry, particularly suppliers, to converge inputs even further, concentrating old clients, opening up new markets (Africa), while creating common cause with the health and energy industries worldwide.

Since 2008, the world's recent renewed focus on food security and nutrition is allowing the oligopoly formed by the agrochemical corporations to forge new forms of hegemonic governance over food, medicals and fuels ${ }^{4}$. [2]

In 2008, while the G8 launched a public-private partnership initiative called "Global Partnership on Agriculture and Food Security" (GPAFS), most southern governments and Civil Society movements pledged for the improvement of global food and agriculture governance. On 26-27 January 2009, the Rome +1 Summit was held in Madrid. The idea of a 'Global Partnership on Agriculture and Food Security' to tackle the global food and hunger crisis was to be formally launched by President Zapatero and UN SecretaryGeneral Ban Ki-Moon but it didn't happen. Reluctance from key southern governments as well as strong protests from the civil society contributed to strengthen another proposal: the reform of the UN Committee on Food Security (CFS). Despite several difficulties to reach consensus and pressure from some OECD countries in order to reduce its mandate and (or) postpone certain functions for a "second phase", the CFS reform was approved in $2009^{5}$. [1] últimas décadas, à medida que os governos da OCDE criaram novas instituições multilaterais tais como, o Programa Alimentar Mundial (PAM), o Grupo Consultivo em Pesquisa Agrícola Internacional (CGIAR) e o Fundo Internacional de Desenvolvimento Agrícola (FIDA), o apoio para a FAO diminuiu em conformidade. [1]

Simultaneamente, as novas tecnologias desenvolvidas nas últimas três décadas permitiram à indústria fornecedora de factores de produção, concentrar clientes, abrir novos mercados (África) e conjugar esforços com as indústrias de saúde e energia em todo o mundo.

Desde 2008, o renovado foco na segurança alimentar e nutricional, tem permitido ao oligopólio formado pelas indústrias agroquímicas, implementar novas formas de governação hegemónica sobre a alimentação, a saúde e a energia ${ }^{4}$. [2]

Em 2008, enquanto o G8 lançava uma parceria público-privada designada, "Parceria Global contra a Fome", governos de países do Sul e movimentos da Sociedade Civil solicitavam a melhoria da governança global da alimentação e agricultura. Em 26 e 27 de Janeiro de 2009, realiza-se em Madrid a Cimeira Roma + 1. A ideia de uma 'Global Partnership on Agriculture and Food Security' para enfrentar a crise global dos preços dos alimentos ia ser formalmente lançada pelo Primeiro-ministro Zapatero e pelo Secretário-geral da ONU, Mr. Ban Ki-Moon, mas tal não aconteceu. A relutância dos principais governos do Sul, bem como fortes protestos da Sociedade Civil, contribuíram para reforçar outra proposta: a reforma do Comité Mundial de Segurança Alimentar das Nações Unidas (CSA). Apesar de várias dificuldades para alcançar o consenso e pressões de alguns países da OCDE, a fim de reduzir o seu mandato e (ou) adiar determinadas funções para uma "segunda fase", a reforma do CFS foi finalmente aprovada em $2009^{5} \cdot[1]$

\footnotetext{
${ }^{4}$ These companies are usually based in Western Europe and Northern America and worked together in previous international emergency situations like the "bird flu". The international bird flu response has set the international agenda and, consequently, national agendas for controlling bird flu. Funds were generally offered on condition that the governments adhere to guidelines which include controversial measures such as culling, vaccine stockpiling and long-term restructuring of the poultry industry. These have resulted in concrete benefits for the transnational poultry and pharmaceutical companies. ${ }^{5}$ In the second phase the participation of private sector was already expressive counting with support from the Bill and Melinda Gates Foundation.
}

\footnotetext{
${ }^{4}$ Essas empresas possuem, geralmente, sua base na Europa ocidental e América do norte e trabalharam juntos em situações de emergência internacionais anteriores como a "gripe aviária". A resposta internacional á gripe aviária contribuiu para o estabelecimento de uma agenda internacional e, consequentemente, agendas nacionais para controlar a gripe aviária. Os fundos foram oferecidos aos países geralmente na condição de que os governos seguissem directrizes que incluíam medidas controversas como o abate de animais, estocagem de vacinas e reestruturação da indústria aviária. Estas medidas resultaram em benefícios concretos para as indústrias aviárias transnacionais e para as grandes empresas farmacêuticas.

${ }^{5} \mathrm{Na}$ segunda fase, a participação do setor privado já foi expressiva, contando com o apoio da Fundação Bill e Melinda Gates.
} 
The CFS is still the most inclusive UN body for food security and nutrition governance despite the fact that, due to the pressure from some OECD governments, its decisions are not binding. Its existence is particularly important due to the previous dismantling of the UN Standing Committee on Nutrition $(\mathrm{SCN})^{6}$ due to, as pointed out by Valente (2015), its resistance to create aprivate sector constituency (2015). ${ }^{7}$

Its Secretariat now serves basically the needs of Scaling Up Nutrition (SUN), an initiative created with the funds and with the Organizations that withdrew support to the SCN, such as the World Bank, WFP and UNICEF ${ }^{8}$. [4]

An interesting point to note is that in 2009, at the World Economic Forum, a decision was taken in order to invest in a Global Redesign Initiative (GRI). The GRI report, launched in 2010, established the guidelines for influencing several policy areas including in the area of food and nutrition'. The establishment of the Global Food, Agriculture and Nutrition Redesign Initiative (GFANRI) to "guide the development of food and agriculture policy and supportive multi-stakeholder institutional arrangements that will address current and future food and nutrition requirements within the realm of environmentally sustainable development." might have been a crucial step in this direction and will have concrete implications for the future. [3]

\footnotetext{
${ }^{6}$ The UN harmonizing body of global nutrition programming.

${ }^{7}$ As pointed out by Valente, Flavio (2015) " In 2007 the SCNChair alleged that the "nutrition community' was unable to reach consensus on the causes of malnutrition and resulting policies, and that the $\mathrm{SCN}$ was ineffective and needed to be reformed. The Chair proceeded to request - without a discussion with the full Steering Committeean external evaluation of the SCN. The results of this evaluation, funded by the Gates Foundation, were briefly presented to the 2008 SCN annual plenary. These results were coincidentally in line with the recommendations of the renowned 2008 Nutrition Lancet series, also funded by Gates, which basically delinked malnutrition from its social, economic, political and cultural causes, including questions such as who produces the food, how, and for what reason. From 2008 onwards the inclusive annual SCN sessions have been cancelled and the technical working groups have been dormant. In 2010 the Steering Committee, in which civil society representatives were active, was eradicated. Instead the only 'members' of the SCN are now highlevel staff from four UN organizations who were to meet quarterly. However, such meetings after taking place only twice".

${ }^{8} \mathrm{An}$ initiative that is supporting governments in the global south to priorise nutrition in their policy and programme work. The methodology being used considers the organizations of national round tables involving all relevant stakeholders and maximum political priority (normally engaging the prime minister or the President). These multi-stakeholders arrangements are, however, loosely structures serving, basically, the interests of the initiative.

${ }^{9}$ Fontes: http://www3.weforum.org/docs/WEF GRI StrengtheningInternationalCooperation Book 2010.pdf; http://www.dailymotion.com/video/x36188k - acess 20.4.2016
}

O CSA é ainda o mais inclusivo órgão da ONU para a governança de segurança alimentar e nutricional mesmo que, devido à pressão de alguns governos de OCDE, suas decisões não sejam vinculativas. Sua existência é particularmente importante devido ao desmantelamento anterior do Comité Director de Nutrição ${ }^{6}$ devido a, como apontado por Valente (2015), sua resistência para criar ummecanismo para o sector privado $(2015)^{7}$.

O seu Secretariado serve agora, basicamente, a iniciativa " Scaling up Nutrition" (SUN), um "movimento" criado com os fundos e com as organizações que retiraram apoio ao Comité Director de Nutrição, tais como o Banco Mundial, WFP e UNICEF ${ }^{8}$. [4]

Um ponto interessante a notar é que em 2009, no Fórum Econômico Mundial, uma decisão foi tomada a fim de investir numa "Global Redesign Initiative" (GRI). O relatório GRI, lançado em 2010, estabeleceu as diretrizes para influenciar diversas áreas de política, incluindo a área da alimentação e nutrição9 ${ }^{9}$ O estabelecimento da "Iniciativa Global para Reconfiguração da Alimentação, Agricultura e Nutrição" para "guiar o desenvolvimento de mecanismos institucionais multi-actores para apoio ao desenvolvimento de políticas para a agricultura e alimentação no contexto do desenvolvimento sustentável " pode ter sido um passo crucial neste sentido e terá implicações concretas para o futuro. [3]

\footnotetext{
${ }^{6} \mathrm{O}$ orgão das Nações Unidas para harmonização dos programas globais na área da nutrição.

7 Como salientado por Valente, Flavio (2015), “ em 2007 , o Presidente do Comité alegando que a Comunidade da nutrição havia sido incapaz de alcançar consensos e o Comité havia sido ineficaz e deveria ser reformado. O Presidente pediu uma avaliação externa sem que tal tivesse sido suficientemente discutido. Os resultados da avaliação, financiada pela Fundação Bill e Mellinda Gates foram apresentados brevemente ao plenário em 2008. Os resultados foram coincidentemente semelhantes e em linha com os conhecido relatorio "Nutrition Lancet" tambem financiado pela Fundação Bill e Mellinda Gattes o qual basicamente desliga a ma nutrição das suas causas sociais, economicas, politicas e culturais, incluindo questões como quem produz os alimentos, como e para que finalidade. A partir de 2008 as sessões participativas do Comité foram canceladas e seus grupos de trabalho extintos e (ou) adormecidos. Em 2010 o Comité de Direção onde a sociedade civil era ativa, foi extinto. Em substituição, os unicos membros ativos agora são a equipe de alto nivel das quatro Organizações das nações Unidas que devem reunir três vezes por ano. No entanto tais encontros acabaram por ter lugar apenas duas vezes"

${ }^{8}$ Uma iniciativa que está a apoiar os governos no Sul a priorizar o tema da nutrição em suas politicas e programas. A metodologia considera a organização de mesas redondas nacionais, envolvendo as partes interessadas e a máxima prioridade política (normalmente envolvendo o primeiro-ministro ou o Presidente). Esses arranjos multi-actores são informais.

9 Fontes: http://www3.weforum.org/docs/WEF GRI Strengt heningInternationalCooperation Book 2010.pdf; http://www.
} Dailymotion.com/Video/x36188k -acess 20.4.2016 


\section{Possible implications for the future}

It seems that the principal problem of our food system, amongst others, is that (increasingly in the last decades) many people in the world have not had sufficient access to resources to grow, or income to purchase, enough and adequate food. This is affecting more than 3 billion persons worldwide, most of them smallholder farmers or workers excluded from the sector. At the same time, the world now has around 2.5 billion overweight or obese persons. While most relevant stakeholders agree that better governance is fundamental to address the problem, there is a huge discrepancy in terms of what "better" might mean. In terms of the role of the government and possible mechanisms to be implemented, some sectors, including private corporations, tend to consider that governments failed to govern our food system and that public-private partnerships are necessary. However, for others, including the global civil society movement for "food sovereignty" 10 , some governments might have failed but this was precisely caused by a neo-liberal agenda that has been contributing to reduce the effective role of the state.

The idea of multi-stakeholders mechanisms as a basis for food security and nutrition governance is also different. Most aforementioned initiatives with strong private sector participation (including SUN) are creating and (or) stimulating loose and informal multi-stakeholders structures to "govern" food and nutrition security at national, regional and international levels. For other stakeholders, including some participating in the food sovereignty movement, such spaces might replace the legitimate role of governments.

To summarize this point, one can argue that the trend to progressively transfer governance of "conflicting policy areas" from intergovernmental to loose multistakeholder spaces, strongly influenced by the agenda of the private sector, might in the near future bypass legitimate national food security and nutrition institutions and international 'one country one vote' intergovernmental food and nutrition policy spaces, such as the CFS, the World Health Organization (WHO) and the FAO.[4]

In terms of policy and program strategies, visions and respective implications are also different. For the private corporations, markets can be used to solve emerging food and nutrition problems. Under this perspective, for example, supplying industrialized food supplements, nutrient pills and powders, and other means of food fortification can serve public health goals. For others, the way markets are operating is part of the problem. Under

\footnotetext{
${ }^{10}$ Meaning the global Civil Society movement for food sovereignty including "Via Campesina" and other allies
}

\section{Possíveis implicações para o futuro}

Parece que o principal problema do nosso sistema alimentar, entre outros, é que muitas pessoas no mundo (principalmente nas últimas décadas), não possuem acesso a suficientes recursos para produzir, ou rendimentos para comprar uma alimentação suficiente e adequada. Isto afecta mais de 3 mil milhões de pessoas em todo o mundo, a maioria, agricultores familiares ou trabalhadores excluídos do sector. Ao mesmo tempo, o mundo conta agora com aproximadamente 2,5 mil milhões de pessoas com sobrepeso ou obesidade. Enquanto todos os atores interessados concordam que uma melhor governança é fundamental para resolver os problemas existentes, há enormes diferenças em termos do que se entende por "melhor". Em termos do papel do Estado e possíveis mecanismos para implementação, alguns setores, incluindo o sector privado, tende a considerar que os governos não governaram o nosso sistema alimentar e que, por isso, a celebração de parcerias público-privadas são necessárias. No entanto, para outros, incluindo o movimento global da sociedade civil para a "soberania alimentar" 10 , alguns governos podem ter falhado, mas isso foi precisamente causado por uma agenda politica neoliberal que contribuiu para a redução do papel efetivo do estado.

A ideia de mecanismos multi-actores como base institucional para promoção da governança da segurança alimentar e nutricional também é diferente. As iniciativas já mencionadas com uma forte participação do sector privado (incluindo SUN) estão a criar e (ou) estimular a construção de estruturas informais multi-actores para "governar" a segurança alimentar e a nutrição, nos níveis nacional, regional e internacional. Para muitos, incluindo alguns participantes do movimento global pela soberania alimentar, tais espaços podem contribuir para substituir o legitimo papel dos governos.

Para resumir este ponto, pode-se argumentar que a tendência para progressivamente transferir a governação de " áreas políticas de maior conflito" dos espaços Intergovernamentais para espaços multi-actores de curta duração mais influenciados pela agenda do sector privado, pode contribuir para contornar, num futuro próximo, instituições oficiais para governança da segurança alimentar e nutricional e organizações internacionais baseadas no principio - um país um voto - como o CSA, a Organização Mundial de Saúde (OMS) e a FAO. [4] Em termos de políticas, programas e estratégias, as visões e respectivas implicações são também diferentes. Para as corporações privadas, os mercados podem ser usados para resolver os problemas de alimentação e nu-

${ }^{10}$ Significa o movimento da Sociedade Civil global para a soberania alimentar, incluindo a "Via Campesina" e outros aliados 
this vision, efforts to treat food and nutrition as inseparable entities related with the overall sustainability of humanity are crucial aspects to be addressed.

In some countries and regions, as for example, member states of the Community of Portuguese Speaking Countries (CPLP), the creation of national and regional multi-stakeholders mechanisms is being made by governments as part of a broader national food security and nutrition policy approved by the council of Ministers and (or) by national parliaments. Having in mind the above mentioned evolution and its possible implications, this alternative might worth further exploration at national level. At regional level, coherent arrangements can be explored with regional integration bodies. This is actually happening with member states belonging to CARICOM (Caribbean Community), to ECOWAS (Africa) and to CPLP (Community of Portuguese Speaking Countries) amongst others. At the international level, it seems possible and necessary to strengthen the CFS and its national - regional linkages.

\section{Conflict of interests}

The authors declare that there are no financial and/or personal relationships that could be viewed as presenting a potential conflict of interests. trição emergentes. Sob esta perspectiva, por exemplo, fornecer alimentos industrializados tais como suplementos, nutrientes em comprimidos e (ou) pós, e outros meios de fortificação de alimentos, pode contribuir, decisivamente, para servir os objectivos de saúde pública. Para outros, a forma como os mercados estão a operar é parte do problema. Sob esta visão, tratar a alimentação e a nutrição como entidades separadas e não relacionadas com a sustentabilidade geral da humanidade é um aspecto problemático a equacionar.

Em alguns países e regiões, como por exemplo, os Estados-membros da comunidade de países de língua portuguesa (CPLP), a criação de mecanismos multi-actores nacionais e regionais está a ser feita pelos governos como parte de suas políticas de segurança alimentar e nutricional aprovadas pelos Conselhos de Ministros e (ou) pelos parlamentos nacionais. Tendo em mente a evolução acima mencionada e suas possíveis implicações, esta alternativa pode, talvez, ser mais explorada a nível nacional.

Ao nível regional, esta possibilidade pode ser mais explorada, coerentemente, com organismos de integração regional. Isso está acontecendo com os Estados-membros pertencentes a CARICOM (Comunidade do Caribe), à CEDEAO (África) e à CPLP (Comunidade de países de língua portuguesa), entre outros. A nível internacional, parece possível e necessário reforçar o CSA e suas ligações aos níveis regional e nacional.

\section{Conflito de interesses}

Os autores declaram não existir qualquer relação pessoal ou financeira que possa ser entendida como representando um potencial conflito de interesses. 


\section{References/ Referências}

[1] Sarmento, Francisco, The emperor is always hungry, Food Files Magazine, issue 3, ActionAid, 2010

[2] GRAIN, "Fowl play: The poultry industry's central role in the bird flu crisis," February 2006: http://www.grain.org/ briefings/?id=194

[3] Samans, Schwab and Malloch-Brown (Editors), Global Redesign - Strengthening International Cooperation in a more interdependent World, World Economic Forum Davos, 2010

[4] Valente, Flavio Luiz Schieck, The Corporate capture of Food and Nutrition Governance: a threat to Human Rights and Peoples Sovereignty, in "Right to Food and Nutrition Watch, FIAN, Germany, 2015 